\title{
Agreeing to Disagree: Security Council Resolution 1441 and Intentional Ambiguity
}

\section{Michael Byers}

U nited Nations Security Council Resolution 1441, adopted unanimously on 8 November 2002, was initially celebrated as reflecting a newfound sense of unity and resolve among the Council's fifteen members. ${ }^{1}$ The Council recalled its previous resolutions on Iraq, required the Iraqi government to account for all of its chemical, biological, and nuclear weapons, and insisted on full cooperation with UN and International Atomic Energy Agency (IAEA) weapons inspectors-to whom the Council accorded enhanced powers. ${ }^{2}$ The Council also declared that Iraq was in "material breach" of some of the previous resolutions, that any further failure to comply would constitute an additional material breach, that it would "convene immediately" if the inspectors reported such a failure, and that continued violations of Iraq's obligations would result in "serious consequences."

But deep differences soon emerged as to whether the text of the resolution authorized UN member states to use force to uphold its provisions. When the United States and the UK invaded Iraq in March 2003, they claimed this action was authorized; France and Russia, in contrast, maintained that no such authorization was present. The same divergence of opinion was evident among many of the nonpermanent members of the Council, the 176 UN member states not on the Council, and academic international lawyers. Today, the differences over Resolution 1441 are seen as reflecting a profound crisis for the UN and international peace and security more generally. ${ }^{3}$

In this article, I examine in detail Resolution 1441: its background, the text itself, and the debates that continue to rage. I question how, after eight weeks of intense negotiations, the provisions of a five-page document could be interpreted in such very different ways. I conclude that the potential for dispute over the resolution was not an accident, that the document contains intentional ambiguities - in other words, that the Council members negotiated and agreed to language that they knew could be used to support arguments on both sides. 
That said, all of the Council's members likely believed that their particular understanding of the resolution was legally correct. The differing interpretations were not necessarily the result of bad legal advice. They derived at least in part from subtle, preexisting differences in interpretive approach-differences that only become significant in situations of textual ambiguity and that become all the more significant when, as in the case of Resolution 1441, there is no international court or tribunal with jurisdiction to resolve the resulting dispute.

The international lawyers who work for governments are aware of these differing interpretive approaches and their potential effects. The members of the Security Council agreed to the ambiguities of Resolution 1441 with their eyes open, knowing that they were neither resolving nor papering over their differences. Instead, they were simply agreeing to disagree.

Those states that opposed a U.S.-led war on Iraq had several possible motives for accepting these ambiguities. The most obvious was to prevent, or at least postpone, a war. Another important but less obvious motive derived from the fact that the ambiguities, by providing scope for opposing legal positions, effectively "de-legalized" the situationthus giving free rein to international politics in a discrete situation where the politics seemed destined to prevail. And this, in turn, helped to protect the existing rules on the use of force from serious harm. In the highly charged circumstances created by President George W. Bush's clear and firm intent to remove Saddam Hussein from power, Resolution 1441 was, at least for those who supported the UN and the existing rules on the use of force, an exercise in legal damage control.

I begin by canvassing some previous manifestations of intentional ambiguity in international law, before identifying the relevant ambiguities of Resolution 1441 and the key arguments associated with them. I then consider some of the potential policy reasons why different Council members negotiated and accepted a less than clear text. Finally, I suggest several reasons why international lawyers have previously paid little attention to the role of intentional ambiguity, including a perception that recognizing the existence of such ambiguities could undermine the ideal of a determinative, apolitical body of rules. But interdisciplinary work at the interface of international law and international relations has shown that law both reflects and constrains politics and power, and that acknowledging the political underpinnings of international law does not therefore negate the inherent specificity of its rules. Moreover, some areas of international law are evidently more politicized than others-the rules on the use of military force particularly so. Seen from this perspective, the adoption of an intentionally 
ambiguous Security Council resolution in the face of a threatening political convulsion demonstrates a pragmatic awareness of the limits of the law-coupled with a desire to preserve the rules for better days.

\section{Intentional Ambiguity in International Lawmaking}

Unintentional ambiguity in international legal documents is an almost inevitable consequence of the character of negotiations, where delegates frequently have to resolve complex issues and widely divergent interests under severe time constraints. But one should not underestimate the frequency with which inconsistencies and ambiguities are intentionally included. States that are unable to secure their desired outcome on a particular negotiating issue may push for ambiguous language so as to reduce the impact of their loss. Likewise, when more or less equally balanced sets of negotiators find themselves in a stalemate, the adoption of an ambiguous text allows all sides to claim victory-particularly when reporting back to their home governments and national constituencies. It may also allow them to apply their own view when implementing the resulting obligations and to maintain their stance through to further negotiations. As Richard Bilder has written, "Often agreement on a particular matter will only be possible through the adoption of very broad language in the text, which in effect leaves the problem for later resolution." 4

The provision on compensation for the expropriation of foreignowned property in the 1974 Charter on Economic Rights and Duties of States provides one example of intentional ambiguity, as Jorge Castañeda explained:

La solution du problème de l'indemnisation consisterait peut-être en une formule qui préserverait la position que l'une et l'autre parties soutiennent depuis près d'un siècle, c'est-à-dire qui serait énoncée en des termes suffisamment généraux et suffisamment abstraits (je serais tenté de dire délibérément ambigus) pour englober les positions respectives sans rien y changer et sans rien trancher. ${ }^{5}$

The 1979 International Convention Against the Taking of Hostages provides another example. The negotiations, the impulse of which was the 1976 Entebbe crisis, involved two very different concerns. ${ }^{6}$ Developed states were worried about their own nationals being taken hostage and wanted a treaty that provided maximum scope for their efforts to address the issue, while imposing stringent cooperation requirements on developing states. Developing states were more concerned about the 
possibility of military interventions directed at the (real or ostensible) purpose of rescuing hostages. A compromise eventually emerged. Although the convention includes a general reaffirmation of the principles of the UN Charter, it neither explicitly grants nor denies a right to use force to rescue hostages on the territory of another state. ${ }^{7}$ As Francis Boyle explained,

This outcome ... essentially left the seminal question of the Entebbe raid unanswered. . . . All members of the Hostages Committee abstained from a revival of the Security Council debates on the legality of the Entebbe raid precisely in order to avert a breakdown of the Committee proceedings. Instead, they operated on the foundation of the least common denominator among them and drafted a hostages convention on that compromise basis. ${ }^{8}$

However, one should not assume that the adoption of an ambiguous text leaves the balance of negotiating power unaltered: the mere act of framing the dispute in writing might subsequently provide an advantage to one side. The World Trade Organization's (WTO) Agreement on Trade-Related Aspects of Intellectual Property Rights (TRIPS) provides one example of how this could occur. Article 27(3)(b) of TRIPS spells out that "members may also exclude from patentability" the following:

(b) plants and animals other than micro-organisms, and essentially biological processes for the production of plants or animals other than non-biological and microbiological processes. However, Members shall provide for the protection of plant varieties either by patents or by an effective sui generis system or by any combination thereof. The provisions of this subparagraph shall be reviewed four years after the date of entry into force of the WTO Agreement. ${ }^{9}$

The obvious nature of the contradiction, which leaves it frustratingly unclear as to whether states can exclude plants from patents and comparable intellectual property protections, suggests that it was intentional. This suggestion is bolstered by the fact that the parties committed to further negotiations, not on the issue of plant patents as such, but on the existing terms of the provision. And this in turn could have consequences for the outcome of those negotiations, which, instead of being largely political, will now be couched in normative terms and colored by the overall tenor, object, and purpose of the agreement. As Richard Bilder has explained,

Simply having a written agreement may promote general attitudes and establish an institutional framework and negotiating parameters in 
which a more genuine agreement can, over time, be more easily achieved. ... This is particularly so where the only alternative is to defer attempts to reach agreement to a future time when, as the context of negotiation changes, divergent interests become more apparent, and positions harden and become more fixed, even equivocal agreement may be unattainable. ${ }^{10}$

In the case of Article 27(3)(b) of TRIPS, the requirement that "Members shall provide for the protection of plant varieties" will be buttressed by the fact that the treaty as a whole is directed at the worldwide implementation of stringent intellectual property rules, whereas the preceding, contradictory sentence might well be undermined by that same object and purpose. It therefore seems reasonable to conclude that this particular ambiguity reflects a negotiating success for a group of states seeking, through a strategic shaping of the bases for future negotiations, to improve the prospects for a clear requirement of universal plant patentability. As for the states opposed to this outcome, it is possible that they were aware of, and decided to accept, this potential consequence of ambiguity, perhaps because this was the best provision that they could achieve within the broader "package deal" of the WTO agreement, or because the ambiguity at least preserves the possibility of another outcome, should the interests of states or their relative bargaining power change.

Sometimes, the substance of provisions in documents that are adopted in two or more official languages differs between the different language versions. One example is Security Council Resolution 242, which was adopted following the 1967 Six Day War. The French version demands the "retrait des forces armées israéliennes des territoires occupés"-which translates as the "retreat of Israeli armed forces from the occupied territories." In contrast, the English version demands only the retreat "from territories occupied in the recent conflict" and thus arguably does not apply to all the territory, that is, East Jerusalem, the Gaza Strip, the Golan Heights, and the West Bank."1 The inconsistency was intentional, as Guy de Lacharrière explained:

C'est ainsi que certains délégués ont précisé qu'ils étaient prêts à accepter le texte seulement dans une des deux versions, la française pour les uns, l'anglaise pour les autres. Ainsi, l'ambiguïté est apparue comme une condition de l'adoption de la résolution, la divergence des vues ne pouvant être autrement surmontée.

L'ambiguïté, introduite et maintenue sur la demande très pressante d'Israël, peut être considérée comme ayant été, pour cet Etat, un procédé de limitation de l'échec. ${ }^{12}$ 
Much less frequently, but also intentionally, the same group of states will simultaneously adopt two contradictory documents. An example of this occurred with respect to the situation on the Korean Peninsula in 1975. On one and the same day, the General Assembly adopted two texts carrying the same number-3390 (XXX) - and identified as resolutions "A" and "B." Resolution A states that "the Armistice Agreement remains indispensable to the maintenance of peace and security in the area." Resolution B, in contrast, states that "a durable peace cannot be expected so long as the present state of armistice is kept as it is in Korea."13

These five examples demonstrate that intentional ambiguities are part and parcel of international law, included in legal documents as and where necessary, for a variety of reasons. It consequently comes as no surprise to find similar ambiguities in Resolution 1441.

\section{Intentional Ambiguity and Resolution 1441}

A careful perusal of Resolution 1441 reveals grounds for arguments both for and against the existence of a Security Council authorization for the use of force against Iraq in 2003-and this in a document that resulted from eight weeks of negotiations among governments that were working hard either to secure or deny such authorization. The failure to close off one or the other sets of arguments suggests that the ambiguities were intentional and that the potential for deep disagreement over the legal meaning of the document was consciously accepted at the time. ${ }^{14}$

The argument in favor of an authorization was summarized as follows by the attorney general of the United Kingdom:

1. In resolution 678 [of 1990] the Security Council authorized force against Iraq, to eject it from Kuwait and to restore peace and security in the area.

2. In resolution 687 [of 1991], which set out the ceasefire conditions after Operation Desert Storm, the Security Council imposed continuing obligations on Iraq to eliminate its weapons of mass destruction in order to restore international peace and security in the area. Resolution 687 suspended but did not terminate the authority to use force under resolution 678 .

3. A material breach of resolution 687 revives the authority to use force under resolution 678 .

4. In resolution 1441 the Security Council determined that Iraq has been and remains in material breach of resolution 687, because it has not fully complied with its obligations to disarm under that resolution. 
5. The Security Council in resolution 1441 gave Iraq "a final opportunity to comply with its disarmament obligations" and warned Iraq of the "serious consequences" if it did not.

6. The Security Council also decided in resolution 1441 that, if Iraq failed at any time to comply with and cooperate fully in the implementation of resolution 1441 , that would constitute a further material breach.

7. It is plain that Iraq has failed to comply and therefore Iraq was at the time of resolution 1441 and continues to be in material breach.

8 . Thus, the authority to use force under resolution 678 has revived and so continues today.

9. Resolution 1441 would in terms have provided that a further decision of the Security Council to sanction force was required if that had been intended. Thus, all that resolution 1441 requires is reporting to and discussion by the Security Council of Iraq's failures, but not an express further decision to authorize force. ${ }^{15}$

The terms of Resolution 1441 favor this argument in a number of ways. First, the preamble, by expressly referring to Resolution 678, provides support for the assertion that that particular resolution remains in force. Second, although Resolution 1441 does not expressly authorize the use of force, it does expressly adopt the language of "material breach" in a situation where all the members of the Security Council were without doubt as to what the United States and the UK understood that concept to imply-namely, that fundamental failures to comply with Resolutions 687 and 1441 would revive the authorization provided in Resolution 678.16 Third, although Resolution 1441 requires that the Council convene "to consider the situation and the need for full compliance with all of the relevant council resolutions in order to secure international peace and security," it does not expressly state that further action requires a new resolution. This omission enabled the British government to argue:

Had that been the intention, it would have provided that the Council would decide what needed to be done to restore international peace and security, not that it would consider the matter. The choice of words was deliberate; a proposal that there should be a requirement for a decision by the Council, a position maintained by several Council members, was not adopted. ${ }^{17}$

Other aspects of Resolution 1441, however, favor the argument against authorization, which may be summarized as follows:

1. Resolution 687 (read in conjunction with Resolution 686) terminated the authorization to use force that the Security Council had provided 
in resolution 678: any further use of force would thus require a new authorization. This was made particularly clear in the concluding paragraph of Resolution 687, which states that the Council: "Decides to remain seized of the matter and to take such further steps as may be required for the implementation of the resolution and to secure peace and security in the area."

2. To the degree that Resolution 687 constituted a cease-fire agreement, the agreement was between the Security Council and Iraq (although the cease-fire itself applied to Iraq and the "coalition states"). A "material breach" could not revive the right of the coalition states to use force because they were not party to the agreement.

3. Although Resolution 1441 finds Iraq in material breach (and asserts that a further violation will constitute a further material breach), it at no point specifies any legal consequence of this finding.

4. Resolution 1441 does not contain the signal words "use all necessary means," which have traditionally been considered vital to any Security Council authorization.

5. Following its adoption, representatives of all the members of the Security Council, including the United States and Britain, publicly confirmed that Resolution 1441 provided no "automaticity" for the use of force. 18

The terms of Resolution 1441 favor this argument in a number of ways. First, the reference to Resolution 678 is made in the context of "recalling" previous resolutions and is not therefore easily understood as an assertion that the resolution remains in force. Second, Resolution 1441 conspicuously fails to specify the legal consequences, if any, of a finding of material breach, despite the fact that this concept is not an established part of United Nations law. 19 Third, Resolution 1441 does state that, in the event of a report of noncompliance from the UN or the IAEA inspectors, the Council "will convene immediately ... in order to consider the situation and the need for full compliance with all of the relevant Council resolutions in order to secure international peace and security." Fourth, although the Council warns of "serious consequences," it does not, again, employ the words "use all necessary means." Finally, the Council declares its decision "to remain seized of the matter."20

A more detailed analysis of the respective arguments would delve into the context and origins of Resolutions 678, 687, and 1441, the practice of the Security Council and its member states from 1990 onward, and the views expressed by two successive UN secretariesgeneral. However, my point is not that one full set of arguments is better 
than the other-good international lawyers can and will argue about the legality of the Iraq war for decades to come-but rather that both sets of arguments are at least plausible. And that the plausibility of each is maintained by ambiguities in Resolution 1441 that were almost certainly intended by, or at least evident to, all of the Council's members.

Further evidence of the intentional character of the ambiguities appeared after the Iraq war began. For example, in May 2003, the Financial Times reported that, in late February 2003, Jean-David Levitte, the French ambassador to Washington, met with U.S. deputy national security adviser Stephen Hadley to discuss British and U.S. efforts to secure a "second resolution." According to the Financial Times, "Mr. Levitte urged Mr. Hadley to drop the second resolution. It would, he warned, cause unnecessary diplomatic damage. If they went to war without another resolution, its legality would be hazy, whereas if they went for it and failed, the legality would be in no doubt."21 Levitte was reportedly acting on direct instructions from President Jacques Chirac. 22 James P. Rubin has reported that Levitte also met with VicePresident Richard Cheney. According to Rubin,

France's ambassador in Washington, Jean-David Levitte, told Cheney in February that Washington and Paris should simply "agree to disagree." Through other diplomatic channels, the French advised the Americans to bypass the council entirely. "Your interpretation [of 1441] is sufficient [to justify war]," they counseled Washington, and "you should rely on your interpretation." 23

\section{Potential Policy Reasons for the Intentional Ambiguities}

Each of the fifteen members of the Security Council would have had its own, often complex combination of reasons for agreeing to the ambiguities of Resolution 1441. For example, London was acutely conscious of its own public's skepticism with respect to the degree and imminence of the threat posed by Iraq and to Prime Minister Tony Blair's unwavering support for President George Bush's policies. ${ }^{24} \mathrm{~A}$ credible argument based on Security Council resolutions would allay some of that skepticism by providing the apparent imprimatur of international law and thus of a greater degree of multilateral legitimacy. The British government mishandled other aspects of the situation, releasing dossiers on Iraqi weapons of mass destruction that were later revealed to be plagiarized or otherwise suspect, ${ }^{25}$ and pushing for the "second" Security Council resolution that in the end could not be achieved. ${ }^{26}$ Yet the ambiguities of Resolution 1441 provided an essential fallback: despite its various public 
relations problems-including a nasty spat with France-the government could at least show that the use of force was not demonstrably illegal. And this, the polls indicated, mattered greatly to British voters. ${ }^{27}$

The U.S. government also had an interest in securing the apparent imprimatur of multilateral legitimacy. In the autumn of 2002 , a majority of Americans wanted the Bush administration to pursue the Iraq matter through the UN. ${ }^{28}$ And while many within that majority might well have been satisfied simply with an effort to secure UN backing, the need to retain London's support provided a strong incentive for a positive negotiating result. ${ }^{29}$ Blair provided the administration with enhanced credibility-polling higher in the United States than the president himself and providing a more articulate voice in favor of war. ${ }^{30}$ Although the American public did not seem particularly concerned as to whether the war was permissible under international law, it did need convincing that the war was necessary. ${ }^{31}$ Blair's continued support and advocacy may have been decisive. ${ }^{32}$

Paris and Moscow both had significant financial incentives for preventing war, given the substantial debts owed them by Iraq. ${ }^{33}$ Their agreement to Resolution 1441 was consistent with this interest, in that the resolution provided for the resumption of weapons inspections, which in turn postponed the war and raised the possibility, however slight, of full Iraqi compliance. Yet the French and Russians would also have been thinking of other consequences of war, including its possible effects on the existing international order. ${ }^{34}$ Their concern would have been heightened by President Bush's 1 June 2002 claim to an extended right of preemptive self-defense, ${ }^{35}$ as subsequently fleshed out in the National Security Strategy of the United States of America on 20 September 2002. ${ }^{36}$ And it would have reached fever pitch as a result of the threat, made explicit in Bush's address to the General Assembly on September 12, that the world organization would be rendered irrelevant if no Security Council resolution was achieved ${ }^{37}$ Both governments were aware that a U.S. and British-led war against Iraq that was justified solely on the basis of self-defense against a developing (as opposed to truly imminent) threat could have modified customary international law (if the action was widely supported) or at least, by demonstrating the willingness of two traditionally strong supporters of international law to stretch the rules, thus could have undermined the rule of law in international peace and security. ${ }^{38}$ In either case, the central role of the Security Council, and with it the importance of France and Russia as vetoholding permanent members, would have been significantly diminished. Both states therefore had a strong incentive to cushion the impact of any such war on the existing rules and institutions governing the use of 
force, even if that meant providing the United States and Britain with a more credible legal justification.

China, although not a major creditor of Iraq, would have made calculations similar to those of France and Russia, as would many of the nonpermanent members. ${ }^{39}$ Some, such as Syria, while vehemently opposed to a war in Iraq, would also have been very concerned to avoid displeasing the reigning superpower. ${ }^{40}$ Resolution 1441 enabled them to placate the United States without visibly giving in to its demands. The end result was that the intentional ambiguities of the resolution served the interests of all the members of the Security Council by providing a plausible justification for the war while maintaining legal arguments in opposition.

\section{Disputed Foundations: \\ The Law and Politics of Interpretation}

Most international lawyers regard the law through an adjudicative prism. And courts and tribunals must render a clear decision on the arguments presented to them; they are not, in legal terminology, allowed to render a non liquet.$^{41}$ International lawyers therefore tend to believe that there is always a "right answer" and that all that it takes to find the answer is a rigorous assessment of the "sources" of international law. These sources, as famously set out in Article 38(1) of the Statute of the International Court of Justice, include treaties; customary international law (made up of state practice and the legal opinions of states); general principles of law; and, on a subsidiary basis, the decisions of courts and the views of academics. ${ }^{42}$ Today, the sources also include, at a minimum, those Security Council resolutions adopted under Chapter VII of the UN Charter and thereby endowed with binding legal force. ${ }^{43}$

Where gaps exist, either in the source material or in the application of that material to a specific dispute, international lawyers seek to fill them through analogical reasoning from related precedents, rules, or principles. ${ }^{44}$ But the analogies chosen, or indeed the relative weight accorded to different source materials, remain somewhat discretionary and, as a result, different international lawyers sometimes assess the sources in slightly different ways. ${ }^{45}$ Nowhere is the impact of such subtle differences in approaches to the sources more apparent than with respect to the debates over Resolution 1441.

Although the various members of the Security Council would have been aware that the ambiguities of Resolution 1441 provided room for arguments both for and against the existence of an authorization to use 
force, they still likely believed that their particular understanding of the resolution was legally correct. As compared to most other countries, the United States in recent decades has tended to place more weight on the "object and purpose" of international documents and less weight on their actual terms. The most famous manifestation of this tendency occurred at the 1968-1969 Vienna Conference on the Law of Treaties, when the U.S. delegation proposed a purposive approach to interpretation that would have emphasized a comprehensive examination of the context of the treaty aimed at ascertaining the common will of the parties-as that will evolved over time. ${ }^{46}$ The proposal was overwhelmingly rejected by the other delegations: Article 31(1) of the 1969 Vienna Convention on the Law of Treaties stipulates that "a treaty shall be interpreted in good faith in accordance with the ordinary meaning to be given to the terms of the treaty in their context and in the light of its object and purpose." 47 As important, Article 32 restricts consideration of the "preparatory work of the treaty ... to determine the meaning" to situations when "the interpretation according to article 31 " has left the meaning "ambiguous or obscure" or led to a result "which is manifestly absurd or unreasonable." 48 In other words, preparatory documents and records of negotiations cannot generally be used for interpretive purposes.

Notwithstanding Articles 31 and 32, the United States still tends to prefer a more contingently purposive and less textually oriented approach, most notably with respect to the UN Charter. One of the more extreme examples of this arose during the 1999 Kosovo crisis, as Rubin explained:

There was a series of strained telephone calls between [U.S. Secretary of State Madeleine] Albright and [UK Foreign Secretary Robin] Cook, in which he cited problems "with our lawyers" over using force in the absence of UN endorsement. "Get new lawyers," she suggested. But with a push from Prime Minister Tony Blair, the British finally agreed that UN Security Council approval was not legally required. ${ }^{49}$

Unlike the UN Charter, Security Council resolutions are not treaties. They resemble executive orders more than contracts, and the interpretive rules that apply to them might therefore be somewhat different. One of the very few authoritative guides to their interpretation is the following passage from the International Court of Justice's 1971 Namibia Advisory Opinion: "The language of a resolution of the Security Council should be carefully analysed ... having regard to the terms of the resolution to be interpreted, the discussions leading to it, the 
Charter provisions invoked and, in general, all circumstances that might assist in determining the legal consequences." 50 Unfortunately, the court did not specify any priority among, or the relative weight of, the various indicia.

Relatively little academic writing has been directed to this issueperhaps because the Security Council was blocked for most of the Cold War-and those who have written favor approaches that differ markedly from each other. Michael Wood, the current UK foreign office legal adviser, has advanced a position that takes into account the full background of the Council's involvement with an issue so as to determine the purpose the Council was seeking to achieve:

a. The aim of interpretation should be-to adapt Lord McNair on treaties-to give effect to the intention of the Council as expressed by the words used by the Council in the light of the surrounding circumstances.

b. The interpreter will, even if this is not expressly stated, seek to apply the general principles of interpretation as they have been elaborated in relation to treaties. The interpreter is likely to turn to the rules in articles 31 to 33 of the Vienna Convention, especially the general rule in article 31.1 and the supplementary means referred to in article 32 .

c. But caution is required. SCRs [Security Council resolutions] are not treaties: indeed the differences are very great. Nor are SCRs necessarily all of the same nature. SCRs must be interpreted in the context of the United Nations Charter. It becomes highly artificial, and indeed to some extent is simply not possible, to seek to apply all the Vienna Convention rules mutatis mutandis to SCRs.

d. In the case of SCRs, given their essentially political nature and the way they are drafted, the circumstances of the adoption of the resolution and such preparatory work as exists may often be of greater significance than in the case of treaties. The Vienna Convention distinction between the general rule and the supplementary means has even less significance than in the case of treaties. In general, less importance should attach to the minutiae of language. And there is considerable scope for authentic interpretation by the Council itself. ${ }^{51}$

Such a purposive approach leads relatively easily to a presumption in favor of an authorization to use force when a resolution is adopted in a situation where (1) the Council has previously identified a threat to international peace and security, (2) the Council has imposed strict conditions on the state posing the threat, and (3) that state has conspicuously failed to fulfill the entirety of those conditions. Although the presumption may be countered by clear evidence to the contrary, textual ambiguities are read, where possible, in a manner that is consistent with the view that the Council intends its demands to be complied with and, 
if necessary, enforced. It will already be apparent that this was the approach used by Washington and London to interpret Resolution 1441.

In contrast, Jochen Abr. Frowein, the recently retired director of the Max Planck Institute for Comparative Public Law and International Law, has advocated an interpretive approach that is more restrictive than that applied to treaties. He begins by discounting the relevance of the subjective intentions of Security Council members:

The resolution is not based on the common will of all those concerned. It is based on the common will of the majority of the members of the Security Council, including the permanent members, at least by abstention. This means that States against whom the Security Council exercises its power under Chapter VII have not contributed to the formulation of the resolution. As far as they are concerned the resolution has the same sort of objective existence as laws or administrative acts in a specific legal system. Therefore, the objective view of the neutral observer as addressee must be the most important aspect for the interpretation. Subjective intentions of some members of the Security Council, particularly intentions covered by the formulation or hidden in specific wording can, at least in principle, not be seen as in any way decisive. 52

Frowein then suggests that the nonparticipation of the addressees of Council resolutions requires the reactivation, in this context, of a venerable presumption:

An old rule of interpretation of international treaties, frequently invoked before the Vienna Convention on the Law of Treaties, was the rule according to which treaties must be interpreted as respecting the sovereignty of States as far as possible. The idea behind that rule was that States may not be presumed to have given up their sovereign rights in a treaty. The Vienna Convention did not include such a rule. In fact, the International Law Commission was of the opinion that the starting point must always be the intention of the parties as expressed by the specific language of the treaty. This is in line with the nature of a treaty as an instrument in which the consensus among the parties has been expressed.

It is quite different with Security Council resolutions, particularly from the point of view of the state against whom enforcement measures are being taken. Such a resolution is the legal basis for the most severe encroachment upon the sovereignty of a member of the United Nations. It is submitted, therefore, that for the interpretation of such a resolution the old rule according to which limitations of sovereignty may not be lightly assumed is fully justified. Only where the use of force against a sovereign state is clearly authorized by a resolution this is [sic] in fact lawful under United Nations law. ${ }^{53}$ 
The presumption, it should be noted, is a specific application of the more general "Lotus principle": that restrictions on the freedom of states cannot be presumed. ${ }^{54}$

The disagreement over Resolution 1441 indicates that many countries subscribe to the more textually oriented approach advanced by Frowein. Such an approach, modeled on Articles 31 and 32 of the Vienna Convention on the Law of Treaties, essentially considers that the Council only means what it specifically says. There is, consequently, an interpretive presumption against the authorization of military force. This presumption is consistent with a related view that exceptions to the general prohibition on the use of force set out in Article 2(4) of the UN Charter should be interpreted narrowly. ${ }^{55}$

Although my own preference is for the more restrictive of these two interpretive approaches, it must be acknowledged that the coexistence of the two approaches and their consequent presumptions makes it possible for an ambiguous resolution to mean very different things to different states. The adoption of differing interpretations of Resolution 1441 was, again, probably less the result of bad legal advice or a cynical distorting of the law than it was of the application of different interpretive approaches to a situation of textual ambiguity.

The relative lack of writing on the issue of interpreting Security Council resolutions suggests that this is an underdeveloped area of customary international law that has itself remained somewhat ambiguous - to the point that differing approaches could be employed without this in itself clearly violating the law. From a legal perspective, one of the more interesting aspects of the war in Iraq is that this debate has become fully engaged. The respective positions are now clear, and in one prominent instance a number of countries have had to take sides. But single crises-and the state practices associated with them-do not generally make or change customary international law; what matters instead is the behavior of states over time. For the moment, all that can be conclusively said is that there was a sufficient absence of agreement over the interpretation of Resolution 1441 to indicate that the interpretive approach preferred by the United States and the United Kingdom has not yet become legally required. At the same time, those two countries may have succeeded in maintaining or perhaps even extending what might be called the "sphere of plausibility" with regard to arguments on this issue. As Sir Arthur Watts has posited,

There is room for the view that all that States need for the general purposes of conducting their international relations is to be able to 
advance a legal justification for their conduct which is not demonstrably rubbish. Thereafter, political factors can take over, and the international acceptability or otherwise of a State's conduct can be left to be determined by considerations of international policy rather than of international law. 56

The law governing the interpretation of Security Council resolutions is not clear-cut, and it remains to be seen toward which, if any, direction a degree of clarity evolves.

For the moment, the United States and Britain can rely on their purposive approach, if not to generate widespread legal agreement, at least to help protect their actions against charges of illegitimacy. As in the 1999 Kosovo crisis, the wider compass of legitimacy may, in practical terms, be considered more important than particular disputes about the law. 57 Yet it is also possible that the United States is attempting to secure legal status for its preferred approach to the interpretation of Security Council resolutions. If so, it has one significant advantage, in that the greater the ambiguousness of a rule, the more scope power and influence will have to affect its application. ${ }^{58}$ In this instance, the interpretation of any given resolution will turn on its language and the factual circumstances surrounding its adoption and implementation-as those various factors are assessed by individual states and groups of states. And the ability of the powerful to influence these assessments could be considerable. Over time, the United States could thus, potentially, secure sufficient acquiescence to the application of its preferred approach-to change, or at least stretch, the interpretive rules. The only way to guarantee that this does not happen would be for the Council to ensure that the language of all its resolutions was clear and precise. And in many circumstances this will not be politically feasible; instead, the choice-as in November 2002-will be between an ambiguous resolution and no resolution at all.

It is also possible that different interpretive approaches-and the different conclusions to which they may lead-could be mutually sustainable. As has already been explained, different legal conclusions can even deliberately be fostered, so as to avoid confrontation or otherwise preserve equilibrium between states that are prepared, in the final analysis, to neither agree nor disagree. Contrary to the instincts of many lawyers, states sometimes do adopt texts that are designed to "de-legalize" a situation.

That the members do so is entirely consistent with the fact that the Security Council is a political body with considerable discretionary power. Within the sphere of international peace and security, its lawmaking capacity is limited only by the ability of its members to agreeand, perhaps, by a handful of fundamental "peremptory rules" referred to as jus cogens. ${ }^{59}$ The Council can impose legal obligations on states 
and remove obligations from them. There is nothing in the Charter to suggest that the Security Council lacks the capacity to adopt a resolution that is deliberately open to different interpretations.

Moreover, since such a resolution could, in certain circumstances, cushion the impact of an otherwise unauthorized action on existing rules and institutions, acknowledging this possibility hardly diminishes the importance of international law and international lawyers. Instead, recognizing that legal texts and those who draft them can play this additional role-protecting the international system from permanent harm during the more politically charged moments of international affairsbuttresses one of the key conclusions of interdisciplinary work at the interface of international law and international relations. Since international law both reflects and constrains politics, power, and now the long-term impact of political convulsions on the international legal system, acknowledging the political underpinnings of the law does not negate the inherent specificity of its rules. ${ }^{60}$

All that said, attempts at de-legalizing a particular situation could be undermined by subsequent events. In the aftermath of the Iraq war, the failure of U.S.-led weapons inspectors to find evidence that Saddam Hussein posed an imminent threat has weakened the claim, not that Resolution 1441 provided authorization, but that any such authorization was relied upon appropriately by the United States and Britain. Similarly, the ongoing reluctance of many states to support the U.S.-led occupation of Iraq confirms that Washington and London's interpretation of Resolution 1441 (and its antecedents) was not widely shared. Moreover, it seems that other states are currently exercising even more caution with respect to the language of new Security Council resolutions. Resolution 1483, adopted on 22 May 2003, was very tightly worded so as to leave little scope for arguments that it provided ex post facto authorization of the war. ${ }^{61}$ The same is true of Resolution 1511, adopted on 16 October 2003, even though this last resolution did authorize a U.S.-led multilateral force to provide "security and stability" in Iraq. ${ }^{62}$ Intentional ambiguity is not a panacea; it is a legal safety valve that helps to buy time, in the hope that the problems giving rise to its deployment can be addressed later, in circumstances more favorable to the continued rule of law-and to real diplomatic agreement.

\section{Notes}

Michael Byers is professor of law at Duke University. His latest edited books are The Role of Law in International Politics (2000) and, with coeditor Georg 
Nolte, United States Hegemony and the Foundations of International Law (2003).

1. See, for example, Jeffrey Fleishman, "World Sees Unanimous U.N. Vote as Triumph of Diplomacy," Los Angeles Times, 10 November 2002, p. 19.

2. SC Res. 1441, UN Doc. S/Res/1441 (8 November 2002), available online at http://www.un.org/documents/scres.htm (accessed 3 November 2003).

3. James Traub, "The Next Resolution," New York Times, 13 April 2003, sec. 6, p. 50. For an extreme view, see Michael J. Glennon, "Why the Security Council Failed," Foreign Affairs 82, no. 3 (May-June 2003): 16.

4. Richard Bilder, "The Office of the Legal Adviser: The State Department Lawyer and Foreign Affairs," American Journal of International Law 56 (1962): 654. For an extensive discussion, see Guy de Lacharrière, La politique juridique extérieure (Paris: Economica, 1983), pp. 89-103.

5 . Fourteenth session of the Council on Trade and Development, 20 August 1974, Doc. TD/B (XIV)/Misc. 8. (My translation: "The solution to the problem of compensation may consist in a formula which preserves the position which both parties have supported for almost a century, that is to say, which is expressed in sufficiently general and abstract terms [I am tempted to say deliberately ambiguous] to encompass the respective positions without changing anything there and without settling anything.")

6. See Francis Boyle, "International Law in Time of Crisis: From the Entebbe Raid to the Hostages Convention," Northwestern University Law Review 75 (1980): 831-835.

7. International Convention Against the Taking of Hostages, UNGA Res. 34/146 (17 December 1979), reproduced in American Journal of International Law 74 (1980): 277.

8. Boyle, "International Law in Time of Crisis," p. 835.

9. Agreement on Trade-Related Aspects of Intellectual Property Rights, 1994, available online at http://www.wto.org/english/docs_e/legal_e/27-trips. pdf (accessed 3 November 2003).

10. Richard Bilder, Managing the Risks of International Agreement (Madison: University of Wisconsin Press, 1981), p. 39.

11. See John McHugo, "Resolution 242: A Legal Reappraisal of the RightWing Israeli Interpretation of the Withdrawal Phrase with Reference to the Conflict Between Israel and the Palestinians," International and Comparative Law Quarterly 51 (2002): 815; Shabtai Rosenne, “On Multi-Lingual Interpretation," Israel Law Review 6 (1971): 360.

12. De Lacharrière, La politique juridique extérieure, p. 92. (My translation: "As it happens, certain delegations indicated that they were prepared to accept the text only in one of the two versions, the French version for some, the English for others. The ambiguity thus appeared as a condition for the adoption of the resolution, the divergence of views being otherwise insurmountable. The ambiguity, introduced and maintained at the strong insistence of Israel, can be considered as having been, for that state, a means for limiting its defeat.") Rosenne, ibid., takes the view that any ambiguity was unintentional.

13. Dietrich Rauschning et al., eds., Key Resolutions of the United Nations General Assembly 1946-1996 (Cambridge: Cambridge University Press, 1997), p. 195. 
14. For a similar analysis, see Jane E. Stromseth, "Law and Force After Iraq: A Transitional Moment," American Journal of International Law 97 (2003): 629-631.

15. "Statement by the Attorney General, Lord Goldsmith, in Answer to a Parliamentary Question, Tuesday, 18 March 2003," available online at http:// www.fco.gov.uk/servlet/Front=pagename=OpenMarket/Xcelerate/ShowPage $\& c=$ Page \& $\mathrm{cid}=1007029394383 \& \mathrm{a}=$ KArticle \&aid $=1047661460790$ (accessed 3 November 2003); Times (London), 18 March 2003, p. 2.

16. For an early expression of the U.S. understanding of the application of "material breach" to Resolution 687, see Michael Matheson, "Legal Authority for the Possible Use of Force Against Iraq," American Society of International Law Proceedings 92 (1998): 141.

17. "Iraq: Legal Basis for the Use of Force," annex to "Statement by the Attorney General, Lord Goldsmith," par. 11.

18. UN Doc. S/PV.4644.

19. The concept of material breach is borrowed from the law of treaties. See Art. 60, Vienna Convention on the Law of Treaties, 1155 United Nations Treaty Series 331, International Legal Materials 8 (1969): 679, available online at http://untreaty.un.org/ (accessed 3 Novomber 2003).

20. For a developed set of arguments against the existence of authorization, see Sean D. Murphy, "Assessing the Legality of Invading Iraq," Georgetown Law Journal 92 (forthcoming, 2004).

21. Gerard Baker et al., "Blair's Mission Impossible: The Doomed Effort to Win a Second UN Resolution," Financial Times, 29 May. 2003, p. 17.

22. Ibid.

23. James P. Rubin, "Stumbling into War," Foreign Affairs 82, no. 5 (September 2003): 54 . Confirmation of these reports may be found in a speech made by the ambassador on 25 March 2003: Jean-David Levitte, "France, Germany and the U.S.: Putting the Pieces Back Together, Address at the Council on Foreign Relations," available online at http://www.cfr.org/publication.php?id=5774 (accessed 3 November 2003).

24. Jean Eaglesham, "Bush Impedes Backing for War," Financial Times, 14 November 2002, p. 2 (reporting polling results that indicated 32 percent of the British population considered Bush a greater threat to world peace than Saddam Hussein and that 46 percent agreed with a characterization of Blair as "Bush's lapdog").

25. Warren Hoge, “Blair Denies Misleading M.P.'s, Saying 'We Did the Right Thing,"” New York Times, 9 July 2003, p. Al0.

26. Leaked drafts of the proposed "second" resolution indicated that it too would not have included an explicit authorization of the use of force. See "U.S.-British Draft Resolution Stating Position on Iraq," New York Times, 25 February 2003, p. A14. However, Blair succeeded in convincing the British press that what mattered most was the adoption of any second resolution and not its actual terms. See generally Baker et al., "Blair's Mission Impossible."

27. In a YouGov poll conducted 14-16 March 2003, 76 percent responded positively to the following question: "If the United Nations Security Council decides to launch military action against Iraq, should Britain contribute troops to such an action?" But only 32 percent responded positively to the following question: "If a majority on the Security Council does NOT back the use of force 
against Iraq, and the United States launches such an action, should Britain contribute troops to the US-led action?" YouGov Survey Results, "A Possible War in Iraq, Prepared for Jonathan Dimbleby-Showdown in Iraq," 17 March 2003, available online at http://www.yougov.com/ (accessed 3 November 2003).

28. In a New York Times/CBS poll conducted 3-5 October 2002, 63 percent responded "wait for inspectors" when presented with the following question: "Should the U.S. take military action against Iraq fairly soon or wait and give the U.N. more time to get weapons inspectors into Iraq?" Only 30 percent of those questioned responded "take action." See Adam Nagourney and Janet Elder, "Public Says Bush Needs to Pay Heed to Weak Economy," New York Times, 7 October 2002, p. Al.

29. Krishna Guha and James Harding, "UK Ready to Ignore UN Veto on Iraq and Join US-Led War," Financial Times, 7 March 2003, p. 3.

30. Stephen Robinson, "Prime Minister Is America's Star of Breakfast TV," Daily Telegraph, 27 March 2003, p. 9.

31. Patrick E. Tyler, "A New Power in the Streets," New York Times, 17 February 2003, p. A1.

32. James Harding, "US President Telephones World Leaders for a Fourth Day in Succession in Battle to Get a Second UN Vote," Financial Times, 14 March 2003, p. 2 (citing research from the National Journal showing that 77 percent of Americans said, "We absolutely need to have British support in the event of war in Iraq").

33. William Boston, "Europe Shifts to Post-War Focus," Christian Science Monitor, 20 March 2003, p. 3.

34. Francis Fukuyama, "End of the Postwar Alliance Pact," Yomiuri Shimbun, 16 March 2003, p. 8.

35. Remarks by President George W. Bush at the 2002 graduation exercises of the United States Military Academy, West Point, New York, 1 June 2002, available online at http://www.whitehouse.gov/news/releases/2002/06/ 20020601-3.html (accessed 3 November 2003).

36. National Security Strategy of the United States, 20 September 2002, available online at http://www.whitehouse.gov/nsc/nss.pdf (accessed 3 November 2003).

37. President's remarks at the United Nations General Assembly, 12 September 2002, available online at www.whitehouse.gov/news/releases/2002/09/ 20020912-1.html (accessed 3 November 2003).

38. Michael Byers, "Preemptive Self-Defense: Hegemony, Equality and Strategies of Legal Change," Journal of Political Philosophy 11 (2003): 171-190; "Adoption of Policy of Pre-emption Could Result in Proliferation of Unilateral, Lawless Use of Force, Secretary-General Tells General Assembly," UN press release $S G / S M / 8891,23$ September 2003, available online at http:// www.un.org/News/Press/docs/2003/sgsm8891.doc.htm (accessed 3 November 2003).

39. Chris Buckley, "China Tiptoes Between Opposing the War and Not Angering U.S.," International Herald Tribune, 25 March 2003, p. 4.

40. Nicholas Blanford, "Shrewd Syrians Still Sitting on the Fence," Times (London), 29 November 2002, p. 18.

41. Hersch Lauterpacht, "Some Observations on the Prohibition of Non Liquet and the Completeness of the Legal Order," in Symbolae Verzijl: Présentées au professeur J.H.W. Verzijl à l'occasion de son LXXX-ième anniversaire 
(The Hague: Martinus Nijhoff, 1958), p. 196. It is widely accepted that the principle does not apply to "advisory opinions" rendered by the International Court of Justice, on one view because there the Court has not been charged with settling a particular legal dispute. See Prosper Weil, "'The Court Cannot Conclude Definitively . . 'Non Liquet Revisted," Columbia Journal of Transnational Law 36 (1997): 109.

42. Art. 38(1), Statute of the International Court of Justice, available online at http://www.icj-cij.org (accessed 3 November 2003).

43. Thomas M. Franck, Recourse to Force: State Action Against Threats and Armed Attacks (Cambridge: Cambridge University Press, 2002), pp. 5-9.

44. Vaughan Lowe, "The Politics of Law-Making: Are the Method and Character of Norm Creation Changing," in Michael Byers, ed., The Role of Law in International Politics (Oxford: Oxford University Press, 2000), p. 207.

45. Michael Byers, "Review of Thomas Franck, Recourse to Force: State Action Against Threats and Armed Attacks" (Cambridge: Cambridge University Press, 2002); American Journal of International Law 97 (2003): 721.

46. UN Conference on the Law of Treaties, Official Records (1st sess., 1969), pp. 167-168.

47. Art. 60, Vienna Convention on the Law of Treaties, 1155 United Nations Treaty Series 331 . On the reaction of other states, see also Official Records, ibid., pp. 168-185.

48. Ibid.

49. James P. Rubin, "Countdown to a Very Personal War," Financial Times, 30 September 2000 , p. 9.

50. ICJ Reports (1971), p. 53.

51. Michael C. Wood, "The Interpretation of Security Council Resolutions," Max Planck Yearbook of United Nations Law 2 (1998): 95.

52. Jochen Abr. Frowein, "Unilateral Interpretation of Security Council Resolutions-a Threat to Collective Security?" in Volkmar Götz, Peter Selmer, and Rüdiger Wolfrum, eds., Liber amicorum Günther Jaenicke-Zum 85. Geburtstag (Berlin: Springer, 1998), p. 99 (footnote omitted).

53. Ibid., p. 112 (footnote omitted).

54. See, Lotus Case (1927) PCIJ Reports, Ser. A, No. 9, p. 18. For the more specific rule, Frowein cites Territorial Jurisdiction of the International Commission of the River Oder (1929) PCIJ Reports, Ser. A, No. 23, p. 26.

55. See Jules Lobel and Michael Ratner, "Bypassing the Security Council: Ambiguous Authorizations to Use Force, Cease-fires and the Iraqi Inspection Regime," American Journal of International Law 93 (1999): 125-130.

56. Sir Arthur Watts, "The Importance of International Law," in Michael Byers, ed., The Role of Law in International Politics (Oxford: Oxford University Press, 2000), p. 8.

57. See, for example, Independent International Commission on Kosovo, Kosovo Report (Oxford: Oxford University Press, 2000), available online at http://www.reliefweb.int/library/documents/thekosovoreport.htm (accessed 3 November 2003); Foreign Affairs Committee (UK), Fourth Report-Kosovo (23 May 2000), pars. 137-138, available online at http://www.fas.org (accessed 3 November 2003).

58. For a similar argument, see Nico Krisch, "More Equal Than the Rest? Hierarchy, Equality and U.S. Predominance in International Law," in Michael Byers and Georg Nolte, eds., United States Hegemony and the Foundations of 
International Law (Cambridge: Cambridge University Press, 2003), pp. 147149.

59. See Arts. 53, 64, Vienna Convention on the Law of Treaties, supra, note 19.

60. For representative literature, see Judith Goldstein, Miles Kahler, Robert Keohane, and Anne-Marie Slaughter, eds., special issue, Legalization and World Politics, International Organization 54, no. 3 (2000); Anne-Marie Slaughter, "International Law and International Relations," Recueil des cours 285 (2001):1; Byers, The Role of Law in International Politics; Jutta Brunnée and Stephen Toope, "International Law and Constructivism: Elements of an Interactional Theory of International Law," Columbia Journal of Transnational Law 39 (2000): 19.

61. SC Res. 1483, UN Doc. S/Res/1483 (22 May 2003), available online at http://www.un.org/documents/scres.htm (accessed 3 November 2003).

62. SC Res. 1511, UN Doc. S/Rẹs/1511 (16 October 2003), available online at http://www.un.org/documents/scres.htm (accessed 3 November 2003). 